\title{
Optimal bracing type and position to minimize lateral drift in high-rise buildings
}

\author{
O. Alshamrani ${ }^{1}$, G. G. Schierle ${ }^{2}$, K. Galal ${ }^{1}$ \& D. Vergun ${ }^{2}$ \\ ${ }^{I}$ Department of Building, Civil, and Environmental Engineering, \\ Concordia University, Montreal, Canada \\ ${ }^{2}$ USC, School of Architecture, Los Angeles, USA
}

\begin{abstract}
Selection of high-rise bracing type and position is based on many factors: their degree of resistance to lateral forces, cost, complexity of connection and assembly, and the integration with Architectural objectives. This paper includes selection of the optimal bracing type and position for a high-raise office building in Dammam Saudi Arabia. This 900 square meters per floor prototype is used as case study to compare four bracing types: single diagonal bracing, chevron shape bracing, cross (X) bracing and eccentric bracing; as well as two positions: bracing at the core and external parameter bracing (building facade). The case study building height is 40 stories in an area of high wind velocity $(145 \mathrm{~km} / \mathrm{h})$ where no critical seismic force is recorded. The STAAD Pro 2005 software is used to analyze these systems according to allowable stress requirements for an objective function to minimize drift for wind speed of 145 kilometers per hour. The result of this study shows that adding bracing members to the moment frame structure increases stability and reduces drift. Chevron bracing and cross bracing have the highest resistance to the lateral drift compared to the others; but cross bracing is more costly due to more joints. Therefore chevron is the optimal bracing type. Also this study shows that adding the braces to the core of building reduces the drift much more than adding them to the building facades.
\end{abstract}

Keywords: optimal, lateral drift, cross bracing, diagonal bracing, eccentric bracing, chevron bracing stability, stiffness.

\section{Introduction}

Selection of optimal bracing type and position in high rise buildings is a very significant factor to control the lateral drift caused by lateral load. Controlling 
the lateral drift is very essential to provide comfort to human beings and avoid sickness motion. In addition, large drift may cause danger to life and cause façade failure, or even might cause building collapse. Since wind load is more critical than seismic load in Saudi Arabia; this paper investigates wind effect on high-rise Steel buildings. Since wind load increases with height and increases lateral drift, decreasing lateral drift is a vital criterion to select bracing type and position. Basically, this paper investigates the reduction of lateral drift in highrise buildings, nevertheless considering the integration with the architectural objectives, which governs the optimal selection of the bracing type and position in high-rise buildings.

\section{Background}

Braced frames resist gravity load in beam bending and column compression; and lateral load in axial compression and tension [1]. Braced frames are stiffer than moment frames, which is good in areas of wind load but it will increase seismic forces. However, braced frames are not as rigid as shear wall systems. There are several types of braced frame like single diagonal, chevron shape brace, V shape brace, cross $(\mathrm{X})$ bracing, and $\mathrm{K}$ bracing [1].

$\mathrm{X}$ bracing is considered as stiffer than others, which increase the rigidity of the building. On the other hand, it has more connection joint that will increase the construction cost. Selecting the type of braces depends on their position in the building. Also, it depends on the function of the place. For example, if the space has openings like doors or windows one may select chevron shape bracing to allow openings between braces. However, some architects like to put the braced frame in the external frame to give expression to the building while others like to put it in the internal core of the building [4].

Axial action of braces resists the lateral shear caused by lateral load. Hence, it is an efficient system for steel structures to resist the lateral force and provide strength and stiffness as well ${ }^{2}$. Because the lateral force is reversible, the axial force acting in columns, girders, bracings also reverse. Hence, the braces must act in both compression and tension, but it must be so efficient to resist the compression force [2]. To resist the lateral shear the girders are in compression while the braces are in tension or compression. Compression in leeward columns and tension in windward columns resist the external moment. The flexural deformation in structure is caused by the shrinking of the leeward columns and the expansion of the windward columns [2]. The high-rise buildings deflect predominantly in flexural mode while the low-rise buildings deflect predominantly shear mode [2].

\section{Methodology}

Selection of optimal bracing type and position process is shown in figure 1. Four bracing types: (single diagonal bracing, (X) cross bracing, chevron shape bracing, and eccentric bracing) are tested in this study; as well as two positions: bracing at the core and external parameter bracing (building facade). This process implies eight combinations of bracing types and position for 40 story 
building height. Each bracing's type and position is passed through criteria process to minimize lateral drift (main criterion) as well as integration with architectural objectives (secondary criterion). All bracing types and positions combinations are entered to the design evaluation of STAAD Pro 2005. By comparing all result to the steel moment frame system, the optimal selection of the bracing type and position is verified. Accordingly, minimal lateral drift is achieved.

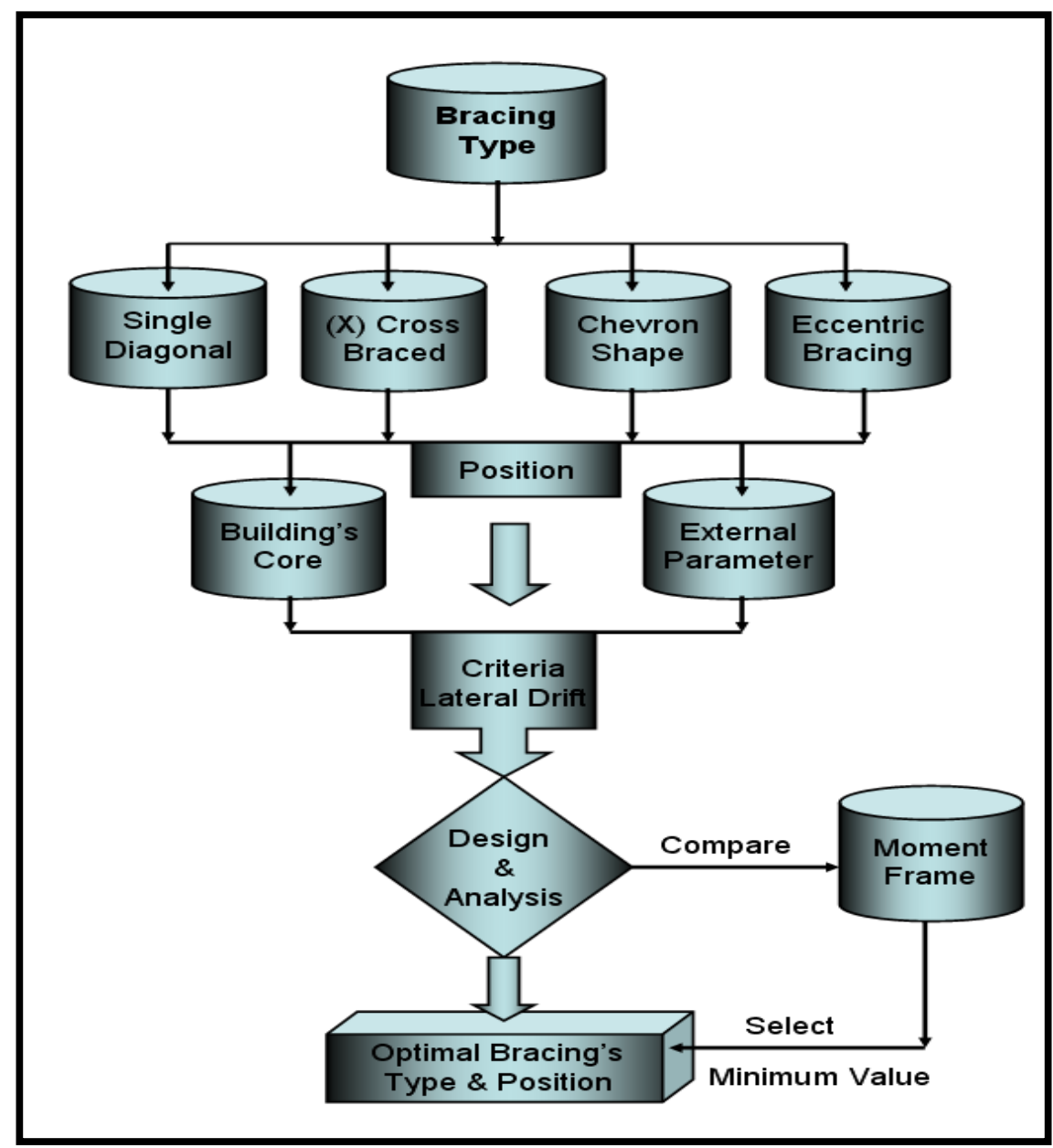

Figure 1: $\quad$ Selection of the optimal bracing's type and position process.

\section{Assumptions}

Using the structural design and analysis software (STAAD Pro), the case study assumed: International Building Code IBC 03; 145 kilometre/hour maximum 
wind speed; allowable stress design method for schematic structural design; material strength of steel: $50 \mathrm{ksi}$. Structural members are designed to meet the allowable stresses ( $30 \mathrm{ksi}$ steel beam, $25 \mathrm{ksi}$ steel columns and bracings due to column buckling) and maximum allowable lateral drift (h/200). Gravity load was assumed applied simultaneously with wind load, assuming combined dead and live loads uniform distributed loads of $1.7 \mathrm{kip} / \mathrm{ft}$. Lateral load per level was assumed as shown in Fig. 3 acting on wind and lee sides in Kips.

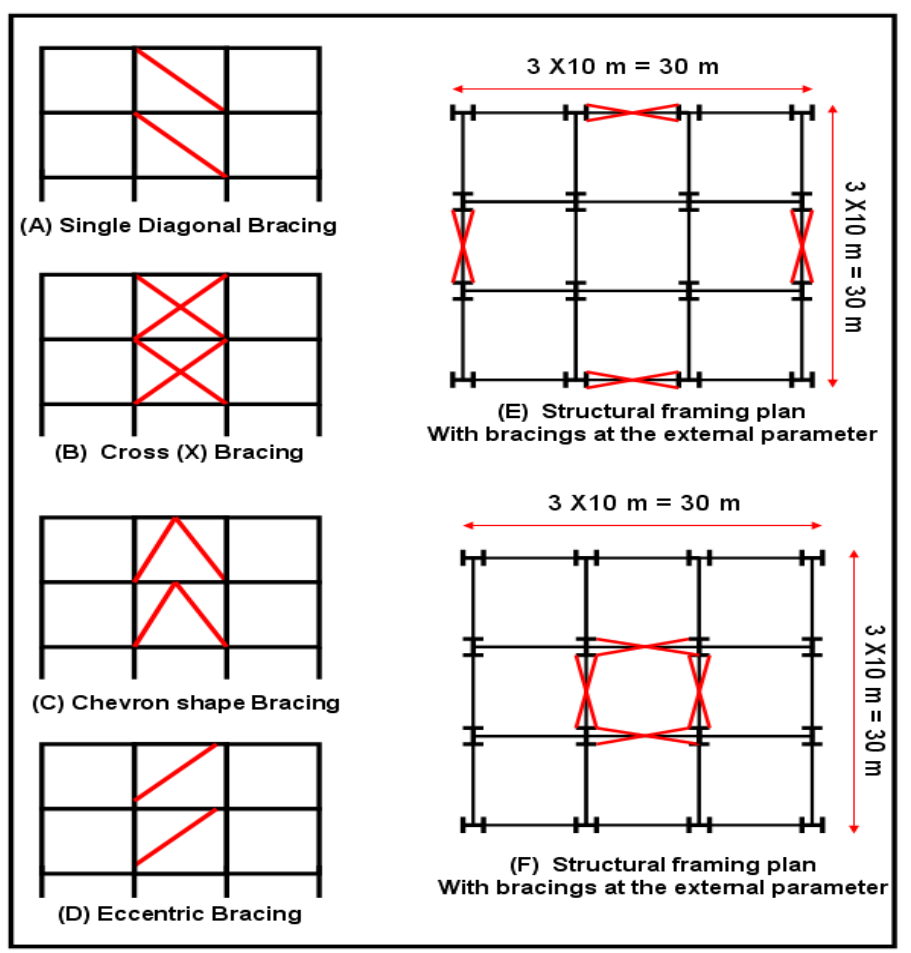

Figure 2: Prototype plans and sections for different bracing types and positions.

Variables investigated in the case study:

- Bracing types (single diagonal, chevron shape, (X) bracing and eccentric bracing) as shown in Fig. 2.

- Bracing positions (at the core and external parameter (building façade)).

The lateral drift is measured at each level after defining member size for strength to assure the actual lateral drift is less than the maximum allowable. The tested case study consists of 3 bay frames with $33 \times 33 \mathrm{ft}(10 \mathrm{X} 10 \mathrm{~m})$ column spacing and $13 \mathrm{ft}(4 \mathrm{~m})$ story height as shown in Fig. 2. 


\section{Wind load distribution}

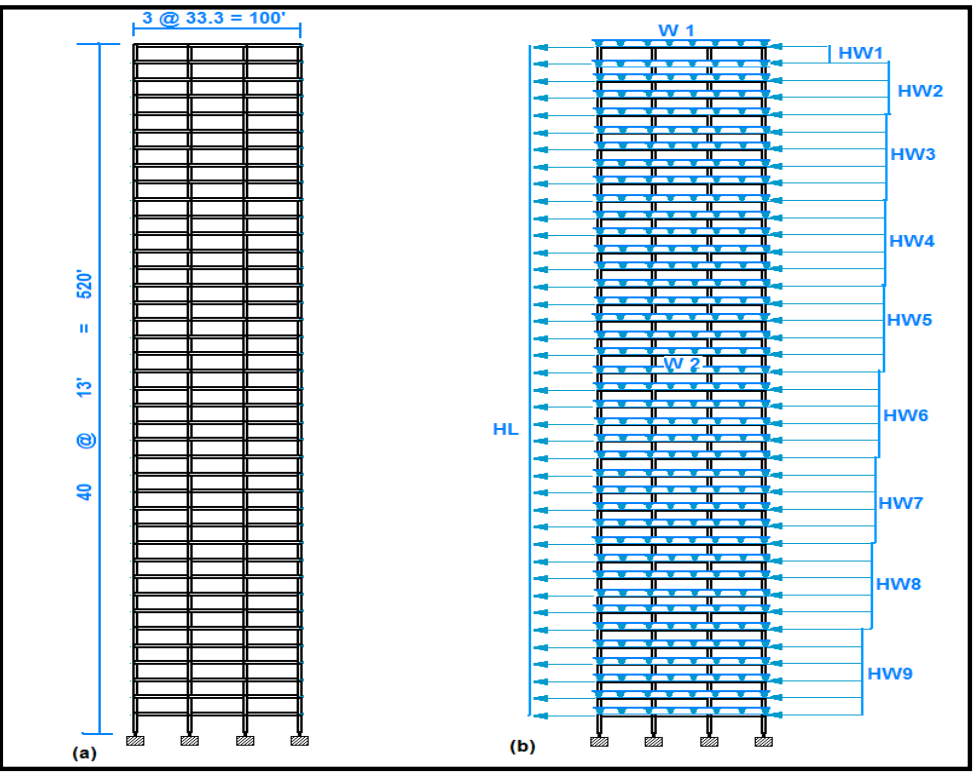

Figure 3: 40 story $(520 \mathrm{ft})$ height prototype frame; Section (a), wind and gravity load (b).

The loads of the 40 story frame are shown at figure 3.

\section{Gravity load:}

Roof $\mathrm{W} 1=0.9 \mathrm{kip} / \mathrm{ft}$

Floor W $2=1.7 \mathrm{kip} / \mathrm{ft}$

\section{Lateral Load:}

Table 1: $\quad$ Wind loads for 40 story steel building.

\begin{tabular}{|c|c|c|c|}
\hline \multicolumn{2}{|c|}{ Windward Side. (Pressure) } & \multicolumn{2}{|c|}{ Leeward \& Internal Pressure } \\
\hline WH 1 & 5.85 kip & \multirow{5}{*}{$\begin{array}{c}\text { Leeward Side. } \\
\text { (Suction) } \\
\text { HL }\end{array}$} & \multirow{5}{*}{7.94 kip } \\
\hline WH 2 & 11.69 kip & & \\
\hline WH 3 & 11.30 kip & & \\
\hline WH 4 & 10.92 kip & & \\
\hline WH 5 & $10.52 \mathrm{kip}$ & & \\
\hline WH 6 & 10.00 kip & \multirow{4}{*}{$\begin{array}{c}\text { Internal } \\
\text { (Pressure) } \\
\text { HL }\end{array}$} & \multirow{4}{*}{3.97 kip } \\
\hline WH 7 & 9.40 kip & & \\
\hline WH 8 & 8.60 kip & & \\
\hline WH 9 & 7.50 kip & & \\
\hline
\end{tabular}




\section{Steel members schedule}

Table 2: $\quad$ Beams schedule for a 40 story steel braced frame.

\begin{tabular}{||c|c|c|c||}
\hline Beam Size & Floor No. & Beam Size & Floor No. \\
\hline W18 x 71 & 39,40 & W18x 158 & $23-27$ \\
\hline W18 x76 & 37,38 & W18x 175 & 18 TO 22 \\
\hline W18 x 86 & 35,36 & W18x 192 & $15-17$ \\
\hline W18 x 97 & 33,34 & W18x 158 & $11-14$ \\
\hline W18 x 119 & $30,31,32$ & W18x 143 & 7 TO 10 \\
\hline W18x 130 & 28,29 & W18x 130 & 1 TO 6 \\
\hline
\end{tabular}

Table 3: $\quad$ Braces schedule for a 40 story steel braced frame.

\begin{tabular}{||c|c|c|c||}
\hline Braces Size & Floor No. & Braces Size & Floor No. \\
\hline W12 14 & 37 to 40 & W12 $\times 35$ & 17 to 21 \\
\hline W12 16 & 32 to 36 & W12 1650 & 13 to 16 \\
\hline W12 19 & 27 to 31 & W12 65 & 8 to 12 \\
\hline W12 26 & 22 to 26 & W12 2679 & 1 to 7 \\
\hline
\end{tabular}

Table 4: $\quad$ Columns schedule for a 40 story steel braced frame.

\begin{tabular}{|c|c|c|c|}
\hline Column Size & Floor No. & Column Size & Floor No \\
\hline W14 x 193 & 37 TO 40 & W14 x 665 & 15,16 \\
\hline $\mathrm{W} 14 \times 211$ & 35,36 & $\mathrm{~W} 14 \times 730$ & 13,14 \\
\hline W14 x 283 & 33,34 & $\mathrm{~W} 14 \times 825$ & 11,12 \\
\hline W14 x 342 & 31,32 & W14 x 1225 & 9,10 \\
\hline $\mathrm{W} 14 \times 370$ & 29,30 & $\mathrm{~W} 14 \times 1305$ & 7,8 \\
\hline W14 x 426 & 27,28 & W14 x 1385 & 5,6 \\
\hline $\mathrm{W} 14 \times 500$ & 23 TO 26 & W14 x 1465 & 3,4 \\
\hline $\mathrm{W} 14 \times 550$ & 21,22 & $\mathrm{~W} 14 \times 1545$ & 1,2 \\
\hline W14 x 605 & 17 TO 20 & ------------ & --------- \\
\hline
\end{tabular}




\section{Bracing frame at the external parameter}

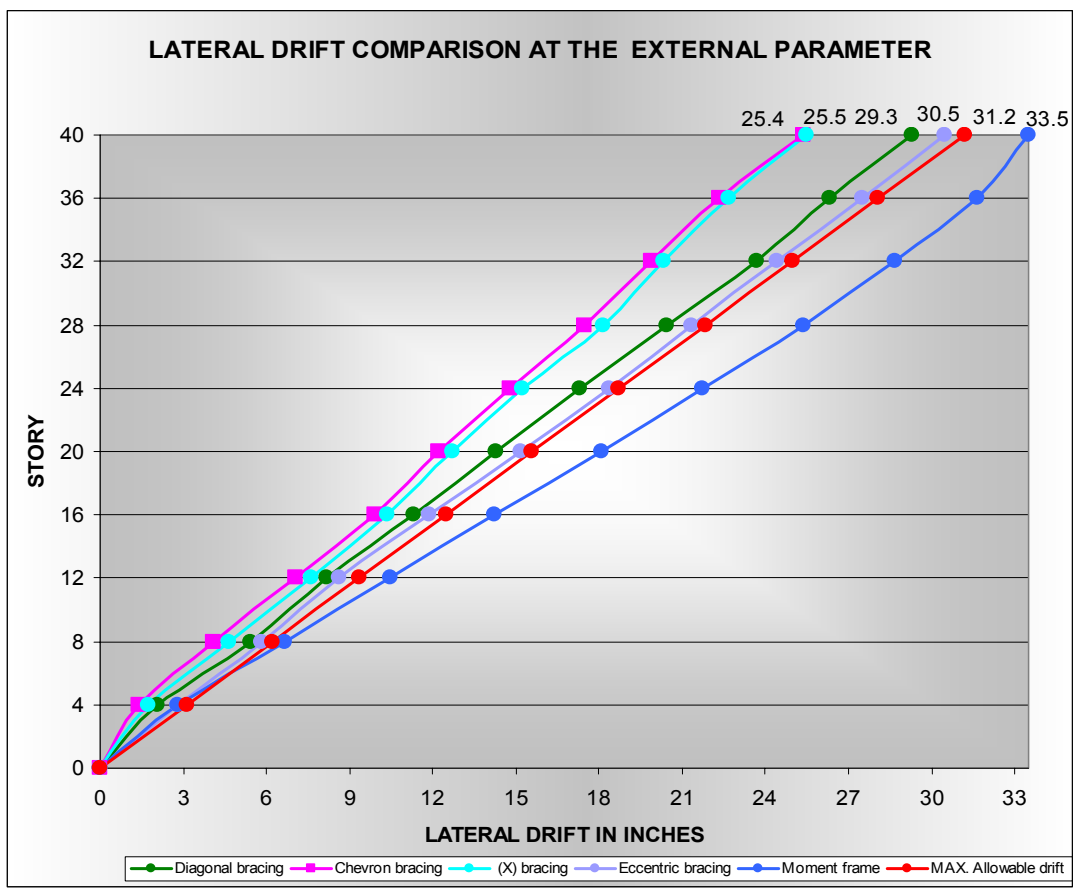

Figure 4: Lateral drift comparison for different bracing types at the external parameter (building façade).

Table 5: $\quad$ Lateral drift for different bracing types at the external parameter.

\begin{tabular}{||c|c|c|c|c|c|c||}
\hline $\begin{array}{c}\text { Floor } \\
\text { Level }\end{array}$ & $\begin{array}{c}\text { Diagonal } \\
\text { bracing }\end{array}$ & $\begin{array}{c}\text { Chevron } \\
\text { bracing }\end{array}$ & $\begin{array}{c}\text { (X) Cross } \\
\text { bracing }\end{array}$ & $\begin{array}{c}\text { Eccentric } \\
\text { bracing }\end{array}$ & $\begin{array}{c}\text { Moment } \\
\text { frame }\end{array}$ & $\begin{array}{c}\text { Allowable } \\
\text { drift }\end{array}$ \\
\hline 4 & 2.12 & 1.41 & 1.75 & 2.81 & 2.79 & 3.12 \\
\hline 8 & 5.41 & 4.11 & 4.65 & 5.80 & 6.66 & 6.24 \\
\hline 12 & 8.22 & 7.07 & 7.61 & 8.62 & 10.47 & 9.36 \\
\hline 16 & 11.31 & 9.89 & 10.34 & 11.91 & 14.22 & 12.48 \\
\hline 20 & 14.27 & 12.21 & 12.72 & 15.20 & 18.06 & 15.60 \\
\hline 24 & 17.32 & 14.78 & 15.21 & 18.40 & 21.76 & 18.72 \\
\hline 28 & 20.45 & 17.51 & 18.15 & 21.33 & 25.35 & 21.84 \\
\hline 32 & 23.67 & 19.87 & 20.31 & 24.41 & 28.66 & 24.96 \\
\hline 36 & 26.34 & 22.35 & 22.70 & 27.48 & 31.66 & 28.08 \\
\hline 40 & 29.30 & 25.40 & 25.50 & 30.50 & 33.50 & 31.20 \\
\hline
\end{tabular}




\section{Bracing frame at the core}

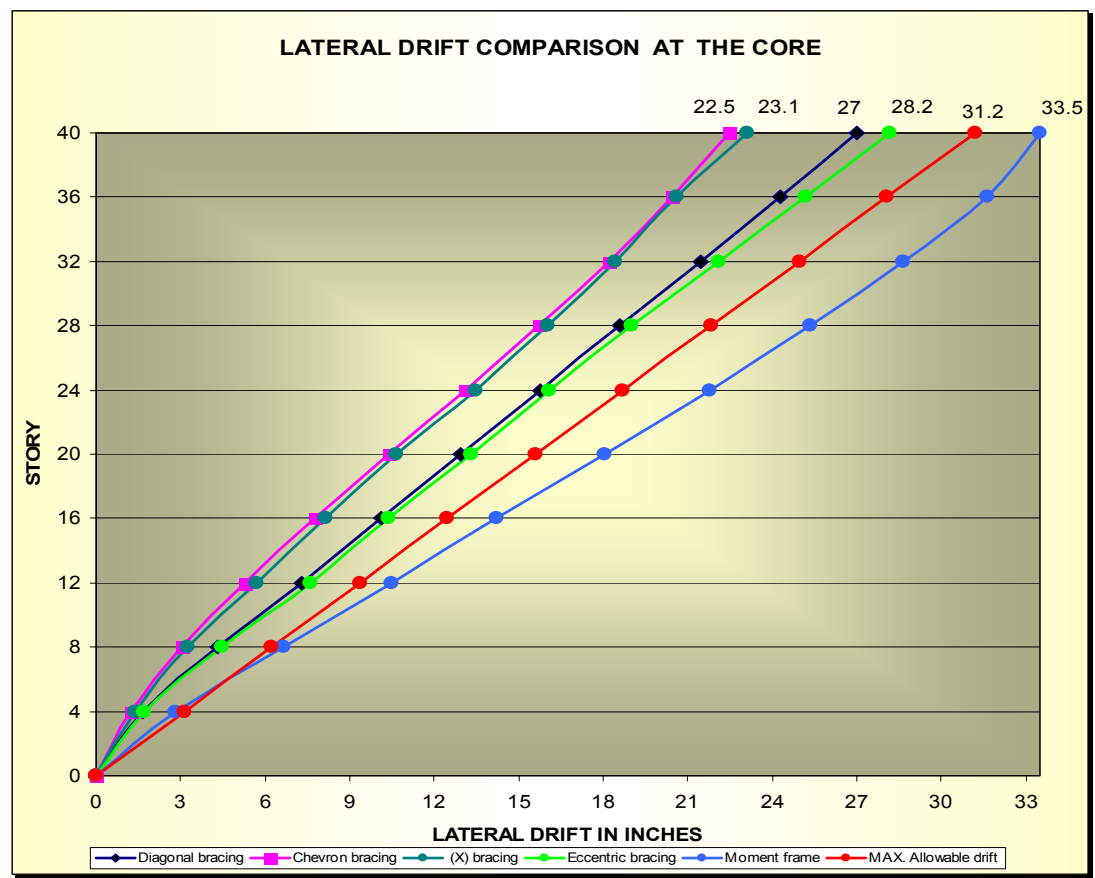

Figure 5: Lateral drift comparison for different bracing types at the core.

Table 6: $\quad$ Lateral drift for different bracing types at the core.

\begin{tabular}{||c|c|c|c|c|c|c||}
\hline $\begin{array}{c}\text { Floor } \\
\text { Level }\end{array}$ & $\begin{array}{c}\text { Diagonal } \\
\text { bracing }\end{array}$ & $\begin{array}{c}\text { Chevron } \\
\text { bracing }\end{array}$ & $\begin{array}{c}\text { (X)Cross } \\
\text { bracing }\end{array}$ & $\begin{array}{c}\text { Eccentric } \\
\text { bracing }\end{array}$ & $\begin{array}{c}\text { Moment } \\
\text { frame }\end{array}$ & $\begin{array}{c}\text { Allowable } \\
\text { drift }\end{array}$ \\
\hline 4 & 1.65 & 1.23 & 1.4 & 1.70 & 2.79 & 3.12 \\
\hline 8 & 4.32 & 3.05 & 3.25 & 4.45 & 6.66 & 6.24 \\
\hline 12 & 7.32 & 5.28 & 5.7 & 7.60 & 10.47 & 9.36 \\
\hline 16 & 10.1 & 7.78 & 8.5 & 10.4 & 14.22 & 12.48 \\
\hline 20 & 12.93 & 10.41 & 10.65 & 13.3 & 18.06 & 15.60 \\
\hline 24 & 15.77 & 13.1 & 13.5 & 16.1 & 21.76 & 18.72 \\
\hline 28 & 18.60 & 15.72 & 16.3 & 19.03 & 25.35 & 21.84 \\
\hline 32 & 21.44 & 18.22 & 18.42 & 22.10 & 28.66 & 24.96 \\
\hline 36 & 24.27 & 20.46 & 20.6 & 25.18 & 31.66 & 28.08 \\
\hline 40 & 27.11 & 22.5 & 23.1 & 28.20 & 33.55 & 31.2 \\
\hline
\end{tabular}




\section{Results}

The result of this study shows that adding bracing members to the moment frame structure increases the stability and reduces drift. The maximum allowable drifts in $\mathrm{x}, \mathrm{z}$ directions (side - sway) of 40 story building with $(520 \mathrm{ft}$ ) height are 31.2 in. The allowable drift is estimated for the seismic load according to the International Building Code (IBC03) is 0.005 times building height. $\mathrm{d}=520 \mathrm{ft} x$ $0.005 \times 12=31.2$ in.

As shown in figure 4. The optimum bracing type at the external parameter (building façade) for a 40 story building is chevron shape bracing with lateral drift (25.4"). This bracing type minimizes lateral drift by $25 \%$ compared to the moment frame system

The second best bracing type at the external frame is $(\mathrm{X})$ cross bracing with lateral drift (25.5"). It minimizes lateral drift by $24 \%$ compared to the moment frame system. The third best bracing type is a single diagonal bracing with lateral drift (29.3"). This type minimizes lateral drift by $13 \%$ compared to the moment frame system. The lowest recorded resistance to drift is provided by the eccentric bracing with lateral drift (30.5"). It minimizes lateral drift by $10 \%$ compared to the moment frame system as shown in fig. 4.

As shown in figures 5. The optimum bracing type at the core of building for a 40 story building is chevron shape bracing with lateral drift (22.5"). This bracing type minimizes lateral drift by $33 \%$ compared to the moment frame system.

The second best bracing type at the core of building is cross (X) bracing with lateral drift (23.07"). It minimizes lateral drift by $31 \%$ compared to the moment frame. The third best bracing type is a single diagonal bracing with lateral drift (27.1"). This type minimizes lateral drift by $20 \%$ compared to the moment frame system. The lowest effective bracing type is the eccentric bracing with lateral drift (28.2"). It minimizes lateral drift by $16 \%$ compared to the moment frame system as shown in fig. 5 .

In addition, this study shows that by adding the braces to the building core, leads to the reduction of lateral drift much more than adding them to the building facades. For example, chevron shape bracing at the external frame recorded a lateral drift of (25.4"), which is $25 \%$ less than the moment frame system. On the other hand, chevron shape bracing at the core recorded a lateral drift of (22.5"), which is $33 \%$ less than the moment frame system as shown in figures 6,7 .

Furthermore, this study shows that chevron bracing and (X) cross bracing have the highest resistance to the lateral force compared to the others; but cross bracing is more costly due to more joints. Hence, chevron shape proves to be the optimal bracing. This optimization also is due to the flexibility of chevron bracing to the integration with architectural objectives criterion. For example, chevron shape bracing allows opening like doors, windows or other services passage while the $(\mathrm{X})$ cross bracing could cause obstacles to some of theses openings and service passages.

This study also shows that 40 story building the total steel weight is 11.5 million $\mathrm{lb}$ for steel moment frame, and 9.8 million for steel braced frame. 


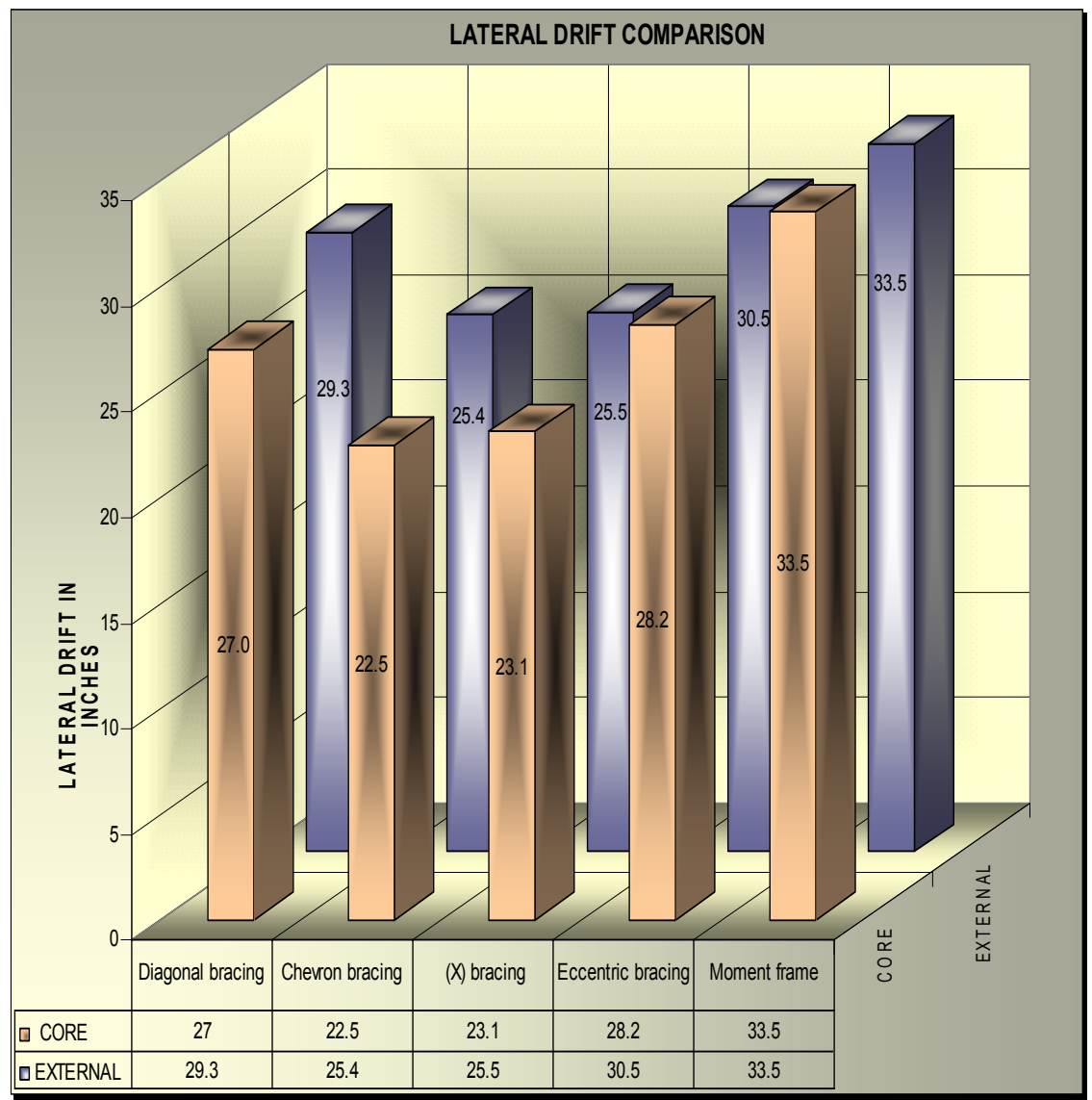

Figure 6: Lateral drift comparisons for different bracing types and positions.

Therefore, adding bracing to steel moment will reduce building mass 1.7 million lb which consequently will reduce the total cost.

\section{Conclusion}

The results of this study show that adding braced frame to steel moment frame building is important to reduce lateral drift as well as building weight and increase stability. The optimum bracing type whether at the facades or the building core for a 40 story building is chevron shape bracing. Also this study shows that adding the braces to the core of building reduce the drift much more than adding them to the facades. The eccentric braced frame is the most flexible braced system as proven in this study. Hence, it is a highly recommended type in seismic zone while it is not appropriate in high wind speed area. Chevron bracing and cross bracing have the highest resistance to the lateral drift compared 
to the others; but cross bracing is more costly due to more joints. Furthermore, chevron bracing is proved to be more flexible to the openings and services passages. Therefore the chevron shape is the optimal bracing type

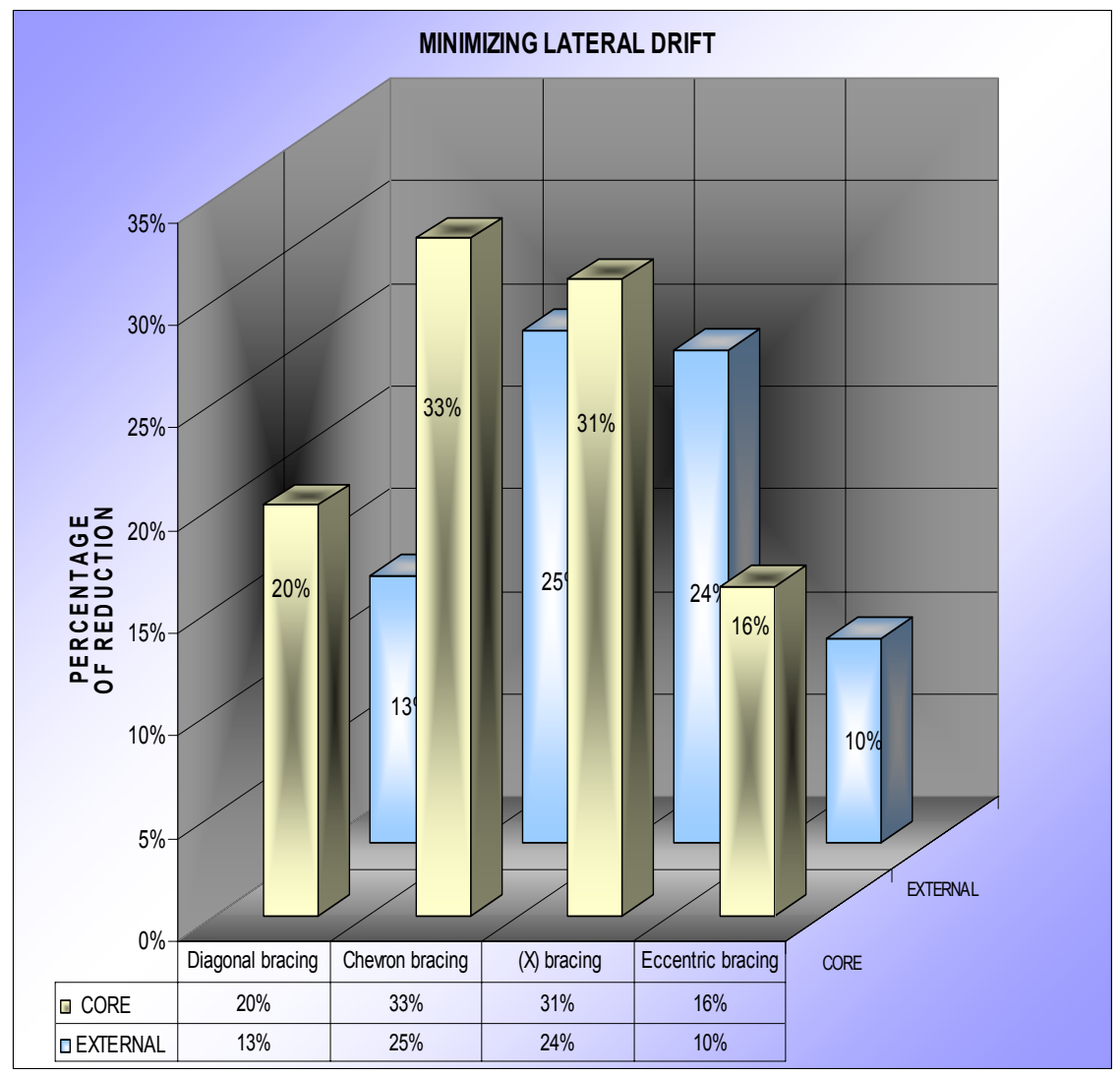

Figure 7: Minimizing lateral drift comparisons for different bracing types and positions.

\section{References}

[1] G. G Schierle, Structure and Design, University Readers, San Diego, 2008 http://www.universityreaders.com/titles/schierle/

[2] Ambrose, James and Vergun, Dimitry, 1995, Simplified Building Design for Wind and Earthquake Forces, University of Southern California, Third Edition, John Wiley \& Sons, Inc: New York. ISBN 0-471-309968-3.

[3] Ambrose, James and Vergun, Dimitry, 1987, Design for Lateral Forces, University of Southern California, John Wiley \& Sons, Inc: New York, ISBN 0-471-84889-1. 
[4] Schierle, G. Goetz, 2006, Structures in Architecture, class notes, ARCH 613 University of Southern California.

[5] Blandra, T., 1993, Vibration of Buildings to Wind and Earthquake Loads, Springer-Verlag: London 1993, ISBN 0-387-19833

[6] IBC 03 International Building Code, Internal Code Council, Fall Church, Virginia, 2003.

[7] AISC Manual of Steel Construction Allowable Stress Design, American Institute of Steel Construction, Chicago, ninth edition, 1991.

[8] CRSI Concrete Reinforcing Steel Institute, Guide to Structural System Selection, 1997.

[9] Cheng-Yu Ho, Lateral Drift Cause by Wind Forces in High-Rise Steel Frame Master of Building Science Thesis, University of Southern California, August 1992.

[10] Cheng-Yu Ho and G. G Schierle, High-Rise Space Frame: Effect of Configuration on Lateral Drift, Proceedings, $4^{\text {th }}$ International Conference on Space Structures, Surrey, Telford Publications. 